\title{
Pembuatan Kompos Granul Ela Sagu Diperkaya Pupuk Majemuk 15:15:15 dan Aplikasinya Pada Budidaya Tanaman Bawang Merah
}

\author{
Making Compost of Sago Ella Granule Enriched with Compound Fertilizer 15:15:15 and Its \\ Application to Shallot Cultivation
}

\section{Maimuna La Habi}

Jurusan Budidaya Pertanian, Fakultas Pertanian Universitas Pattimura, Jl. Ir. M. Putuhena Kampus, Poka Ambon. Penulis Korespondensi: e-mail: monajihan@yahoo.co.id

\begin{abstract}
Effort to reduce the high dependence of farmers on urea fertilizers is adding sago pith waste granular compost as organic fertilizer. This research is conducted to develop granular-enriched compost and evaluate the effectiveness of granular-enriched compost on red onion cultivation. The application of granular-enriched compost was designed in a Randomized Block Design with three replicates. Treatments included 1) without fertilizers (KGES1); 2) the granularenriched compost (8 t/ha) (KGES2); 3) recommended dosage of inorganic fertilizers such as Urea, SP-36, and KCl (KGES3); 4) inorganic fertilizer + granular-enriched compost ( 8 t/ha) (KGES4); 5) $1 / 2 x$ dosage of inorganic fertilizer + granular-enriched compost ( 8 t/ha) (KGES5); 6) $2 \times$ dosage of inorganic fertilizer + granular-enriched compost $(8$ t/ha) (KGES6); 7) $1 / 2 \times$ dosage of inorganic fertilizer + granular-enriched compost (12 t/ha) (KGES7) and 8) $2 \times$ dosage of inorganic fertilizer + granular-enriched compost $(4 \mathrm{t} / \mathrm{ha})$ (KGES8). The granular-enriched compost used in this research has characteristic such as $N 2.43 \%, P 0.59 \%$, and $K 0.87 \%$. Based on this study it could be stated that reduction a half dose of inorganic fertilizer combined with compost granule 12 tha (KGES7) could give profitable dry bulb yield $(13 \mathrm{t} / \mathrm{ha})$ or increased $32 \%$ over the inorganic fertilizer. This combination could possibly reduce the amount of the inorganic fertilizer; therefore, it can be used for improving the effectiveness of fertilizer application on the red onion cultivation.
\end{abstract}

Keywords: granular-enriched compost, inorganic, red-onion

\section{ABSTRAK}

Upaya untuk dapat mengurangi tingginya ketergantungan petani terhadap pupuk urea yang paling murah yaitu dengan penambahan pupuk organik kompos atau kompos granul. Penelitian ini bertujuan untuk mengembangkan pupuk organik diperkaya bentuk granul dari kompos ela sagu dan mengevaluasi efektifitasnya pada budidaya tanaman bawang merah. Rancangan penelitian yang digunakan yaitu rancangan acak kelompok dengan tiga kali ulangan. Perlakuan terdiri atas: tanpa pupuk (KGES1), kompos granul (8 t/ha) (KGES2), pupuk anorganik (Urea, SP-36, dan KCl) dosis anjuran (KGES3), pupuk anorganik + kompos granul ( $8 \mathrm{t} / \mathrm{ha})(\mathrm{KGES} 4), 1 / 2 \times$ dosis pupuk anorganik + kompos granul $(8$ t/ha) (KGES5), 2 kali dosis pupuk anorganik + kompos granul ( $8 \mathrm{t} / \mathrm{ha})(\mathrm{KGES6}), 1 / 2 \times$ dosis pupuk anorganik + kompos granul (12 t/ha) (KGES7) dan 2 kali dosis pupuk anorganik + kompos (4 t/ha) (KGES8). Pupuk kompos granul diperkaya dengan pupuk phonska yang digunakan dalam penelitian memiliki karakteristik sebagai berikut: kandungan $\mathrm{N}=2,43 \%, \mathrm{P}=0,59 \%$ dan $\mathrm{K}=0,87 \%$. Hasil Penelitian menunjukkan bahwa pengurangan setengah dosis pupuk anorganik yang dikombinasikan dengan kompos granul $12 \mathrm{t} /$ ha menghasilkan bobot kering umbi tertinggi (13 t/ha) atau meningkatkan hasil $32 \%$ dari aplikasi pupuk anorganik.

Kata kunci: bawang merah, inorganik, kompost granula diperkaya

\section{PENDAHULUAN}

Bawang merah adalah komoditas sayuran utama yang memberikan kontribusi terbesar ke tiga terhadap total produksi tanaman sayuran di Indonesia $(9,08 \%)$. Pada tahun 2009, total produksinya dapat mencapai 965.164 t/ha atau meningkat $13,07 \%$ dari tahun sebelumnya. Namun di tahun 2008, menjadi 9,28 t/ha pada tahun 2009 (Dirjen Hortikultura, 2010). Berdasarkan hasil penelitian yang diperoleh Balai Penelitian Tanaman sayuran, hasil tersebut masih dapat ditingkatkan hingga mencapai potensi 12-15 t/ha, dengan perbaikan teknologi (Suwandi dan Moekasan, 2008).

Salah satu perbaikan teknologi dalam budidaya tanaman bawang merah yang paling banyak dilakukan 
adalah pemupukan. Pada umumnya petani mengaplikasikan pupuk anorganik secara berlebihan dalam upaya untuk mendapatkan hasil yang lebih tinggi. Beberapa hasil penelitian menunjukkan bahwa penggunaan pupuk kimia dosis tinggi secara terus menerus justru dapat menimbulkan dampak negatif antara lain dengan berkurangnya kualitasium hasil pertanian, menciptakan lingkungan tumbuh untuk perkembangan penyakit seperti Fusar Axyporum dan Alternaria porri (Suryaningsih dan Asandhi, 1992), dapat meningkatkan biaya produksi bawang merah (Suwandi, 1998), menimbulkan defisiensi mikronutrien, menimbulkan ketidakseimbangan sifat-sifat fisikokimia tanah dan produksi tanaman yang tidak berkelanjutan (Jeyathilake et al., 2006), serta dapat merusak struktur tanah dan menyebabkan pencemaran lingkungan karena pupuk N, P, dan K sintetis bersifat mudah hilang karena penguapan dan pencucian (Aisha et al., 2007). Ditambahkan pula oleh Stevenson dan Cole (1999) bahwa faktor utama penyebab hilangnya unsur hara dari dalam tanah terutama unsur $\mathrm{N}$ yaitu Denitrifikasi biologi dan kimia, volatilisasi $\mathrm{NH}_{3}$, pencucian dan erosi. Di lingkungan pertanian, lebih dari dua per tiga bagian Nitrogen yang ditambahkan melalui pupuk tidak dapat diserap oleh tanaman pada masa-masa pertumbuhan, atau telah terjadi kehilangan setengah dari pupuk yang diaplikasikan.

Salah satu upaya untuk mengurangi ketergantungan petani terhadap pupuk anorganik yang tinggi adalah penambahan pupuk organik. Penambahan pupuk organik dapaat memperbaiki struktur tanah dan dapat meningkatkan kegiatan mikroorganisme tanah yang bermanfaat. Salah satu jenis pupuk organik yang murah dan mudah dibuat adalah kompos granul karena ketersediaan bahan baku yang melimpah, seperti kompos ela sagu. Namun demikian, kelemahan dari pupuk organik ini yaitu memiliki kandungan unsur hara yang rendah dan proses ketersediaan bagi tanaman lambat sehingga penggunaan pupuk organik saja belum mampu memberikan hasil ekonomi yang tinggi. Dari sisi kandungan unsur hara, pupuk kompos granul sama dengan pupuk organik lainnya yaitu memiliki unsur hara makro (N, P, K) yang rendah (kurang dari 10\%). Kandungan unsur hara dan tingkat kecepatan dekomposisi ( $\mathrm{C} / \mathrm{N}$ ratio) yang terdapat di kompos ela sagu hampir sama dengan limbah pertanian lain yaitu memiliki kandungan $\mathrm{N}$ total sebesar $1,74 \%$ dengan $\mathrm{C} / \mathrm{N}$ ratio 22,9 (Agustia et al., 2006). Oleh karena itu sangat penting untuk menemukan kombinasi yang tepat antara anorganik dan organik. Jeyathilake et al. (2006) menegaskan bahwa pemanfaatan yang terintegrasi dari pupuk hayati, pupuk organik dan pupuk kimia dapat mengakibatkan peningkatan hasil tanaman pertanian dibandingkan dengan aplikasi eksklusif pupuk kimia.

Diversifikasi produk pupuk organik seperti pembuatan pupuk kompos granul diperkaya dengan cara menambahkan pupuk phonska dalam kompos adalah salah satu langkah yang telah dilakukan untuk meningkatkan status kandungan unsur hara dalam pupuk tersebut. Hasil analisa dasar kompos menunjukkan bahwa kandungan bahan organik dalam kompos ela sagu relatif tinggi yaitu masing-masing $26,85 \%$. Sedangkan untuk kandungan nutrisinya, konsentrasi unsur hara $\mathrm{N}$, $\mathrm{P}$, dan $\mathrm{K}$ yang ada di dalam kompos berbahan baku ela sagu berturut-turut sebesar 1,56\%, 1,03\% dan 0,69\% (La Habi et al., 2006; La Habi et al., 2012). Penambahan pupuk NPK dalam pembuatan kompos diperkaya bentuk granul terbukti mampu meningkatkan kandungan NPK berturut-turut menjadi 3,8\%, 1,5\%, dan 1,8\% (La Habi, et al., 2012). Hasil pembuatan kompos granul ela sagu diperkaya tersebut perlu diujicobakan pada komoditas pertanian, sehingga tujuan penelitian ini ialah menguji dan mengevaluasi kompos granul ela sagu diperkaya dalam memperbaiki kesuburan tanah pada budidaya tanaman bawang merah di Inceptisol.

\section{BAHAN DAN METODE}

\section{Perlakuan dan Rancangan Percobaan}

Penelitian terdiri dari percobaan laboratorium dan percobaan lapangan. Pembuatan pupuk kompos granul dilakukan di UPT Kompos Universitas Brawijaya Malang. Percobaan laboratorium, analisis tanah dan analisis tanaman dilaksanakan di Laboratorium Kimia/Biologi dan Fisika Tanah Fakultas Pertanian Universitas Brawijaya Malang, sedangkan percobaan lapangan dilaksanakan di lahan sawah di Kecamatan Karangploso, Kota Malang dengan jenis tanah inceptisol. Penelitian dilaksanakan mulai bulan Januari hingga Juli 2014. Bahan tanam yang digunakan merupakan varietas bawang merah yang ditanam dengan jarak tanam $70 \times 30$ $\mathrm{cm}$. Komposisi pupuk yang diaplikasikan, baik kompos granul maupun anoganik, sesuai perlakuan. Aplikasi kompos granul ela sagu diperkaya dilakukan dua kali yaitu $50 \%$ pada saat tanam dan $50 \%$ pada 30 hari setelah (HST). Pupuk P diberikan sekaligus pada saat tanam, sedangkan $\mathrm{N}$ dan $\mathrm{K}$ diberikan tiga kali yaitu $50 \%$ pada 10 HST, 30\% pada 30 HST dan $20 \%$ pada 40 HST.

Rancangan penelitian yang digunakan yaitu Rancangan Acak Kelompok (RAK) dengan delapan perlakuan dan tiga kali ulangan. Perlakuan terdiri dari: tanpa pupuk (KGES1), kompos granul ela sagu (8 t/ha) (KGES 2), pupuk anorganik (urea, SP-36, dan $\mathrm{KCl}$ ) dosis anjuran (KGES 3), pupuk anorganik + kompos granul ela $\operatorname{sagu}(8 \mathrm{t} / \mathrm{ha})$ (KGES 4$), 1 / 2 \times$ dosis pupuk anorganik + kompos granul ela sagu ( $8 \mathrm{t} / \mathrm{ha}$ ) (KGES 5), 2 kali dosis pupuk anorganik + kompos granul ela sagu $(8$ t/ha) (KGES 6), 1/2× dosis pupuk anorganik + kompos granul ela sagu (12 t/ha) (KGES 7) dan 2 kali dosis pupuk anorganik + kompos granul ela sagu (4 t ha) (KGES 8).

\section{Pengamatan}

Pengamatan dilakukan mulai umur tanaman 14 hari sesudah tanam (HST), kemudian interval pengamatan dilakukan setiap sepuluh hari sekali hingga 54 HST dan pemanenan pada umur 65 HST. Variabel pengamatan meliputi tinggi tanaman $(\mathrm{cm})$, jumlah daun 
per tanaman, jumlah rumpun per tanaman, jumlah umbi per tanaman dan hasil umbi atau bobot kering panen $(\mathrm{t} /$ ha).

\section{Analisis Data}

Data-data yang diperoleh selama percobaan disusun menggunakan program Microsoft Excel dan dianalisis keragamannya menggunakan program Genstat $12^{\text {th }}$ for windows. Analisis ragam (ANOVA) sesuai dengan rancangan dan pola percobaan yang digunakan yaitu RAK, dan apabila berbeda nyata dilanjutkan dengan uji Duncan multiple range test pada taraf 5\%. Analisis korelasi dan regresi digunakan untuk mengetahui keeratan dan bentuk hubungan antara perlakuan dan variabel yang diamati.

\section{HASIL DAN PEMBAHASAN}

\section{Pembuatan dan Kualitas Pupuk Kompos Granul Diperkaya}

Berdasarkan hasil analisis dasar kualitas unsur hara kompos ela sagu menunjukkan bahwa $\mathrm{pH}$ kompos cenderung agak basa $\left(\mathrm{pH} \mathrm{H}_{2} \mathrm{O} 7,8\right.$ dan $\mathrm{pH} \mathrm{KCl} \mathrm{7,5).} \mathrm{Hal}$ ini menunjukkan bahwa aplikasi kompos berbahan baku ela sagu dapat berfungsi untuk meningkatkan $\mathrm{pH}$ tanah dan mengurangi efek merugikan (penurunan $\mathrm{pH}$ tanah) akibat pemberian pupuk urea ataupun ZA. Kandungan bahan organik dalam kompos ela sagu relatif tinggi yaitu $26,85 \%$. Sedangkan untuk kandungan nutrisinya, konsentrasi unsur hara $\mathrm{N}, \mathrm{P}$, dan $\mathrm{K}$ yang ada dalam kompos berbahan baku ela sagu berturut-turut sebesar $1,56 \%, 1,03 \%$ dan 0,69\%. Apabila dibandingkan dengan kandungan hara dari kotoran hewan seperti sapi dan ayam, kandungan unsur $\mathrm{N}$ dan $\mathrm{P}$, dari kompos granul berbahan baku ela sagu cenderung lebih tinggi, sedangkan unsur $\mathrm{K}$ masih lebih rendah daripada kotoran ayam, namun lebih tinggi dibandingkan kotoran sapi. Kompos yang diproduksi memiliki $\mathrm{C} / \mathrm{N}$ ratio 10 yang berarti bahwa pupuk tersebut termasuk kualitas tinggi dan cepat terdekomposisi sehingga lebih cepat dalam penyediaan unsur hara. Pengkayaan unsur hara yang dilakukan melalui penambahan NPK mampu meningkatkan kandungan $\mathrm{N}$ dan $\mathrm{K}$, masing-masing menjadi $2,41 \%$ dan $\mathrm{K} 0,86 \%$.

\section{Pertumbuhan Tanaman}

Pada awal pertumbuhan, perlakuan belum menunjukkan respon yang nyata pada peningkatan tinggi tanaman, jumlah daun dan jumlah rumpun karena fase awal pertumbuhan, tanaman bawang merah masih memerlukan suplai nutrisi dalam jumlah yang kecil. Sejalan dengan fase vegetatif, suplai hara yang dibutuhkan tanaman untuk pertumbuhan semakin bertambah. Hasil analisis ragam menunjukkan perlakuan pupuk dan kompos granul ela sagu diperkaya berpengaruh nyata pada tinggi tanaman mulai 24 HST dan jumlah daun pada akhir fase pertumbuhan, namun tidak berpengaruh nyata pada jumlah rumpun per tanaman (Tabel 1, 2 dan 3). Perlakuan pemberian pupuk anorganik sudah menunjukkan pertumbuhan panjang tanaman yang cepat pada awal pertumbuhan tanaman (24 HST) dibandingkan perlakuan tanpa pupuk (KGES 1) maupun kompos saja (KGES 2) (Tabel 1).

Pada tahap awal pertumbuhan dan perkembangan tanaman, pelepasan dan ketersediaan nutrisi yang terkandung dalam pupuk anorganik lebih tinggi, sehingga dari hasil penelitian menunjukkan tanaman bawang merah dengan perlakuan kompos (KGES2) pada awal pertumbuhan terlihat lambat, namun tahap selanjutnya tinggi tanaman sama dengan tanaman yang dipupuk anorganik saja maupun kombinasi kompos dan anorganik. Hasil ini sesuai dengan percobaan yang telah dilakukan Seran et al. (20011) bahwa tanaman bawang merah yang dipupuk kompos saja menunjukkan pertumbuhan yang lambat, namun tahap selanjutnya tidak berbeda nyata dengan perlakuan pemberian pupuk anorganik. Arisha et al. (2003) menegaskan pupuk anorganik mampu mempercepat pertumbuhan awal tanaman bawang merah, kemudian pupuk organik memacu pertumbuhan pada tahap berikutnya.

Pupuk organik mengaktifkan banyak species mikroorganisme tanah yang melepaskan fitohormon untuk merangsang pertumbuhan tanaman dan meningkatkan nutrisi tanaman. Organisme tanah tersebut juga memerlukan nitrogen untuk pertumbuhan dan perkembangbiakannya (Ouda dan Mahadeen, 2008).

Tabel 1. Pengaruh aplikasi pupuk kompos granul ela sagu diperkaya pupuk phonska pada tinggi tanaman bawang merah

\begin{tabular}{clllll}
\hline \multirow{2}{*}{ Perlakuan } & \multicolumn{5}{c}{ Rata-rata tinggi tanaman $(\mathrm{cm})$} \\
\cline { 2 - 6 } & 14 HST & 24 HST & 34 HST & $44 \mathrm{HST}$ & 54 HST \\
\hline KGES 1 & 16.43 & $22.82 \mathrm{a}$ & $27.84 \mathrm{ab}$ & $32.44 \mathrm{ab}$ & $31.58 \mathrm{a}$ \\
KGES 2 & 15.84 & $22.83 \mathrm{a}$ & $29.22 \mathrm{ab}$ & $33.66 \mathrm{ab}$ & $35.45 \mathrm{~b}$ \\
KGES 3 & 16.75 & $26.65 \mathrm{~b}$ & $35.42 \mathrm{c}$ & $36.64 \mathrm{bc}$ & $42.04 \mathrm{c}$ \\
KGES 4 & 16.22 & $25.83 \mathrm{ab}$ & $33.35 \mathrm{bc}$ & $39.34 \mathrm{~cd}$ & $41.89 \mathrm{c}$ \\
KGES 5 & 15.93 & $25.71 \mathrm{ab}$ & $34.68 \mathrm{c}$ & $40.09 \mathrm{~cd}$ & $41.98 \mathrm{c}$ \\
KGES 6 & 17.26 & $27.07 \mathrm{~b}$ & $36.67 \mathrm{c}$ & $39.37 \mathrm{~cd}$ & $42.87 \mathrm{c}$ \\
KGES 7 & 17.29 & $27.64 \mathrm{~b}$ & $36.29 \mathrm{c}$ & $41.82 \mathrm{~d}$ & $43.33 \mathrm{c}$ \\
KGES 8 & 16.96 & $28.22 \mathrm{~b}$ & $37.24 \mathrm{c}$ & $42.26 \mathrm{~d}$ & $45.26 \mathrm{c}$ \\
\hline JND 5\% & tn & & & &
\end{tabular}

Keterangan: Angka-angka yang diikuti oleh huruf yang berbeda pada kolom yang sama adalah berbeda nyata pada uji Duncan taraf $5 \%$. tn $=$ tidak nyata 
Tabel 2. Pengaruh aplikasi pupuk kompos granul ela sagu diperkaya pupuk phonska pada jumlah daun pertanaman bawang merah

\begin{tabular}{cccccc}
\hline \multirow{2}{*}{ Perlakuan } & \multicolumn{5}{c}{ Rata-rata jumlah daun per tanaman } \\
\cline { 2 - 5 } & 14 HST & 24 HST & 34 HST & 44 HST & 54 HST \\
\hline KGES 1 & 17.94 & 30.48 & 21.74 & 25.18 & 32.94 \\
KGES 2 & 16.88 & 28.81 & 22.38 & 27.78 & 45.11 \\
KGES 3 & 16.48 & 31.28 & 21.01 & 29.81 & 52.64 \\
KGES 4 & 17.61 & 31.61 & 23.81 & 30.74 & 56.51 \\
KGES 5 & 18.08 & 32.71 & 23.61 & 30.08 & 54.61 \\
KGES 6 & 18.87 & 31.88 & 25.44 & 30.94 & 47.88 \\
KGES 7 & 17.48 & 33.04 & 25.51 & 26.38 & 58.41 \\
KGES 8 & 19.98 & 33.21 & 27.18 & 32.28 & 55.74 \\
\hline JND 5\% & tn & tn & tn & tn & $*$ \\
\hline
\end{tabular}

Keterangan: Angka-angka yang diikuti oleh huruf yang berbeda pada kolom yang sama adalah berbeda nyata pada uji Duncan taraf 5 $\%$. tn = tidak nyata

Namun pada akhir pengamatan terlihat perlakuan kompos saja tidak mampu mengimbangi laju pertumbuhan panjang tanaman dibandingkan pupuk anorganik saja dan kombinasi keduanya. Suplai hara pada perlakuan ini tergantung kandungan hara tanah dan kompos yang semakin berkurang seiring peningkatan kebutuhan tanaman untuk pertumbuhan dan perkembangan.

Pada pengamatan jumlah daun dan jumlah rumpun per tanaman, pelakuan kombinasi pupuk anorganik dan kompos (KGES4, KGES5, KGES6, KGES7 dan KGES8) memberikan hasil yang sama dengan perlakuan anorganik saja (KGES3) dan kompos saja (KGES2) bahkan perlakuan yang tidak dikombinasikan (Tabel 2). Hal ini menunjukkan kandungan nutrisi yang terkandung di dalam tanah berkecukupan bagi perkembangan jumlah daun dan rumpun per tanaman. Status hara dalam kompos granul diperkaya yang diaplikasikan pun dalam kondisi tersedia bagi tanaman.

Analisis laboratorium menunjukkan bahwa kompos granul berbahan baku ela sagu memiliki kandungan $\mathrm{N}$, P lebih tinggi dan $\mathrm{K}$ lebih rendah dari kotoran ayam, sedangkan diversifikasi kompos diperkaya dalam bentuk granul ini meningkatkan kadar NPK berturut turut menjadi $3,9 \%, 1,6 \%$ dan $1,9 \%$ dibandingkan dengan kompos sampah biasa, dengan kadar C/N rasio 10 (La Habi et al., 2012). Kompos yang memiliki $\mathrm{C} / \mathrm{N}$ rasio 10 berarti memiliki kualitas bagus dan cepat terdekomposisi sehingga lebih cepat dalam penyediaan unsur hara bagi tanaman. Ketersediaan unsur $\mathrm{N}$ sangat penting dan diperlukan sepanjang hidup tanaman. Sardi dan Timar (2005) menambahkan bahwa tanaman bawang memiliki kebutuhan $\mathrm{N}$ tinggi untuk memperoleh hasil yang tinggi, terutama pada fase vegetatif tanaman. Unsur nitrogen berperan penting karena unsur hara ini secara aktif terlibat dalam berbagai proses metabolisme dalam tanaman, seperti sintesis protein dan karotenoid. Selain itu ketersediaan N akan mempengaruhi ketersediaan hara ensensial yang lain seperti P dan K.

\section{Hasil umbi bawang merah}

Berdasarkan hasil analisis ragam, hasil yang tidak nyata ditunjukkan oleh jumlah umbi per tanaman (Gambar 1). Hasil ini berkorelasi positif dengan hasil pertumbuhan sebelumnya yaitu jumlah rumpun per tanaman yang juga menunjukkan respon yang sama terhadap semua perlakuan.

Tabel 3. Pengaruh aplikasi pupuk kompos granul ela sagu diperkaya pupuk phonska pada jumlah rumpun pertanaman bawang merah

\begin{tabular}{cccccc}
\hline \multirow{2}{*}{ Perlakuan } & \multicolumn{5}{c}{ Rata-rata jumlah daun per tanaman } \\
\cline { 2 - 5 } & 14 HST & 24 HST & 34 HST & 44 HST & 54 HST \\
\hline KGES1 & 5,68 & 6,21 & 6,81 & 7,82 & 7,94 \\
KGES2 & 5,28 & 6,14 & 7,14 & 8,15 & 8,18 \\
KGES3 & 5,31 & 5,91 & 7,44 & 8,45 & 9,68 \\
KGES4 & 5,14 & 5,84 & 7,28 & 8,29 & 9,71 \\
KGES5 & 5,64 & 6,04 & 8,11 & 9,31 \\
KGES6 & 5,58 & 5,71 & 7,44 & 8,45 & 9,31 \\
KGES7 & 5,38 & 6,14 & 7,78 & 8,76 & 9,64 \\
KGES8 & 5,78 & 6,21 & 8,28 & 9,29 & 10,44 \\
\hline JND 5\% & tn & tn & tn & tn & $*$
\end{tabular}

Keterangan: Angka-angka yang diikuti oleh huruf yang berbeda pada kolom yang sama adalah berbeda nyata pada uji Duncan taraf $5 \%$. tn $=$ tidak nyata 
Berbeda dengan hasil yang diperoleh Seran et al. (2010), aplikasi kompos mampu meningkatkan jumlah umbi tanaman $33 \%$ dibandingkan perlakuan pupuk anorganik saja. Namun rata-rata jumlah umbi yang dihasilkan pada penelitian ini lebih baik (10-14 umbi per tanaman) bila dibandingkan dengan penelitian Sersan et al. (2010) yang hanya menghasilkan 6-9 umbi per tanaman.

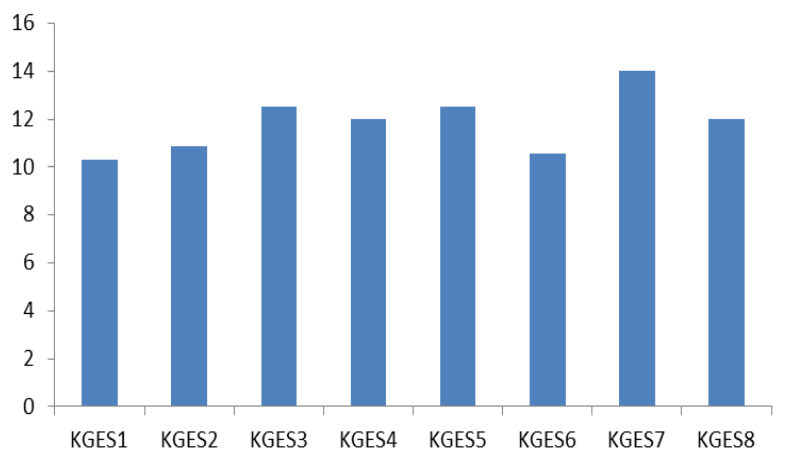

Gambar 1. Aplikasi pupuk kompos granul ela sagu diperkaya pupuk phonska pada jumlah umbi panen per tanaman

Jumlah umbi terbanyak diperolah dari perlakuan pemberian kompos 12 t/ha yang dikombinasikan dengan pupuk anorganik 1/2 dosis anjuran (KGES7). Gamiely et al. (1991) menyatakan bahwa jumlah dan ukuran umbi yang terbentuk dapat ditingkatkan dengan penambahan nitrogen dan kalium setelah penanaman. Selain itu peningkatan umbi bawang merah juga dipacu dengan penambahan pupuk organik, karena tanaman ini merupakan tanaman yang memberikan respon baik terhadap pupuk organik (Purseglove, 1972). Pemberian kompos yang banyak mengandung bahan organik mampu menyediakan lingkungan yang optimal bagi kehidupan dan aktifitas mikroorganisme tanah dan memperbaiki porositas tanah, sedangkan pengkayaan NPK dalam kompos meningkatkan ketersediaan unsur hara lebih cepat sehingga tanaman bawang merah mudah membentuk jumlah umbi per tanaman lebih banyak. Aplikasi kompos granul saja (KGES2) memberikan hasil bobot kering umbi (t/ha) yang sama dengan perlakuan pupuk anorganik (KGES3). Hal ini menunjukkan kandungan hara dalam kompos yang diperkaya mampu menyediakan kebutuhan hara tanaman.

Pupuk anorganik yang dikombinasikan dengan kompos granul mampu meningkatkan hasil 30-47\% dibandingkan dengan pemberian pupuk anorganik maupun kompos granul saja. Hasil yang sama juga diperoleh dari penelitian Seran et al. (2011) yang menemukan bahwa kombinasi pupuk kompos dan anorganik memberikan hasil panen bawang merah yang lebih menguntungkan dibandingkan dengan kompos saja, meskipun kurang berbeda nyata dengan perlakukan pupuk anorganik saja dan didukung oleh hasil penelitian sebelumnya pada bawang merah (Abbey dan Kanton, 2004; Gambo et al., 2008). Hal ini dapat dipahami bahwa kombinasi anorganik dan organik bisa saling mendukung supaya selama masa pertumbuhan, tanaman tidak kekurangan unsur hara. Pupuk anorganik akan cepat melepaskan dan menyediakan nutrisi yang dibutuhkan pada waktu yang tepat, sedangkan pupuk kompos yang mengandung bahan organik tinggi mampu memperbaiki sifat fisik, kimia dan biologi tanah yaitu perbaikan dalam aerasi tanah dan peningkatan kemampuan menahan air. Dari aspek kimia tanah, bahan organik tanah dapat meningkatkan muatan negatif sehingga meningkatkan kapasitas tukar kation (KTK) sedangkan secara biologi bahan organik dapat pula meningkatkan pertumbuhan dan aktifitas mikroorganisme tanah. Pupuk kompos yang diaplikasikan dalam penelitian ini merupakan diversifikasi kompos yang diperkaya unsur hara NPK, sehingga selain berfungsi sebagai penyuplai bahan organik tanah, dapat juga menyediakan hara tersedia bagi tanaman. Oleh karena itu, aplikasinya pada tanaman bawang merah memberikan hasil yang lebih tinggi dari pada pemberian pupuk anorganik saja.

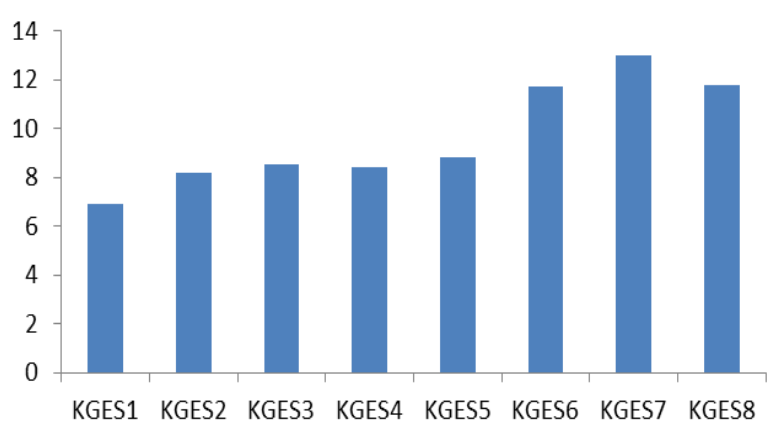

Gambar 2. Pengaruh aplikasi pupuk kompos granul ela sagu diperkaya pupuk phonska pada hasil panen umbi bawang merah

Berdasarkan hasil penelitian ini, pemberian pupuk anorganik berlebihan yaitu dua kali dosis rekombinasi (KGES2 dan PKGES8) tidak menunjukkan hasil peningkatan bobot umbi yang nyata (Gambar 2). Hasil ini sesuai dengan penemuan Ashandi dan Koestani (1990) yang telah membuktikan bahwa cara pemupukan petani bawang merah dengan dosis berlebihan ternyata tidak berbeda nyata dengan cara pemupukan dosis berimbang. Dengan demikian aplikasi pupuk anorganik berlebihan tidak memberikan manfaat ditinjau dari pengaruhnya terhadap pertumbuhan dan hasil bawang merah. Sebaliknya, pengurangan setengah dosis optimum pupuk anorganik yang dikombinasikan dengan pemberiaan kompos granul 8 t/ha (KGES5) dan 12 t/ha (KGES7) menunjukkan hasil yang sama dengan perlakuan kompos granul yg sama dengan perlakuan kompos granul yang dikombinasikan dengan anorganik dosis optimum maupun dua kali dosis optimum. Pengurangan setengah dosis optimum pupuk anorganik yang dikombinasikan dengan kompos granul 8 t/ha (KGES5) dan 12 t/ha (KGES7) masing masing mampu 
meningkatkan hasil $6 \%$ dan $32 \%$ dibandingkan dengan pemberian pupuk anorganik saja (KGES3).

\section{KESIMPULAN}

Kompos granul diperkaya baik yang diaplikasikan secara tunggal maupun dikombinasikan dengan pupuk anorganik dibandingkan dengan pemberian anorganik dan kompos granul saja menunjukkan respon yang sama pada pertumbuhan dan jumlah umbi bawang merah. Kombinasi kompos granul dan pupuk anorganik mampu meningkatkan hasil 30-47\% dibandingkan dengan pemberian pupuk anorganik maupun kompos granul saja. Pemberian pupuk anorganik berlebihan ternyata tidak menunjukkan hasil peningkatan bobot umbi yang nyata. Berdasarkan hasil penelitian ini, pengurangan setengah dosis pupuk anorganik yang dikombinasikan dengan kompos granul $12 \mathrm{t} / \mathrm{ha}$ menghasilkan bobot kering umbi tertinggi (13 t/ha) atau meningkatkan hasil 32\% dari aplikasi pupuk anorganik. Kombinasi ini diharapkan mampu mengurangi penggunaan pupuk anorganik sehingga dapat meningkatkan efektifitas penggunaan pupuk pada budidaya bawang merah.

\section{DAFTAR PUSTAKA}

Abbey, L. and R.A.L. Kanton. 2004. Fertilizer type, but not time of cessation of irrigation, affect onion development and yield in a semi-arid region. Journal of Vegetable Crop Production 9: 41-48. https://doi.org/10.1300/J068v09n02_06

Aisha, A.H., F.A. Rizk, A.M. Shaheen, and M.M. Abdel-Mouty. 2007. Onion plant growth, bulbs yield and its physical and chemical properties as affected by organic and natural fertilization. Research Journal of Agriculture and Biological Sciences 3: 380-388.

Agustia, E., B. Prasetya, dan Z. Kusuma. 2006. Pengaruh ampas tapioka, sampah kampus, dan kotoran ayam terhadap ketersediaan air bagi tanaman sawi (Brassica juncea L.) pada berbagai kelas tekstur tanah. Skripsi.

Arisha, H.M.E., A.A. Gad, and S.E. Younes. 2003. Response of some pepper cultivars to organic and mineral nitrogen fertilizer under sandy soil conditions. Zagazig Journal Agriculture Research 30: 1875-1899.

Asandhi, A.A. dan T. Koestani. 1990. Efisiensi pemupukan pada pertanaman tumpang gilir bawang merah-cabai, I. Efisiensi pemupukan pada pertanaman bawang merah. Buletin Penelitian Hortikultura 19: 1-6.

Dirjen Hortikultura. 2010. Statistik Produksi Hortikultuta Tahun 2009. Direktorat Jenderal Hortikultura Departemen Pertanian. Jakarta. Pp. 267.

Gambo, B.A., M.D. Magaji, A.I. Yakuba, and A.U. Dikko. 2008. Effect of Farmyard manure, nitrogen and weed interference on the growth and yield of onion (Allium cepa L.) at the Sokoto
Rima Valley. Journal of Sustainable development in Agriculture and Environment 3: 87-92.

Gamiely, S., W.M. Randle, H.A. Mills, D.A. Smittle, and G.I. Banna. 1991. Onion plant growth, bulb quality and water uptake following ammonium and nitrate nutrition. HortScience 26: 1061-1063. https://doi.org/10.21273/HORTSCI.26.8.1061

Hilman, Y. dan A. Asgar. 1995. Pengaruh umur panen pada dua paket pemupukan terhadap kuantitas hasil bawang merah (Allium ascalonicum L) kultivar Kuning di dataran rendah. Buletin Penelitian Hortikultura 27: 40-47.

Jayathilake, P.K.S., I.P. Reddy, D. Srihari, and K.R. Reddy. 2006. Productivity and soil fertility status as influenced integrated use of $\mathrm{N}$-fixing biofertilizers, organic manures and inorganic fertilizers in onion. The Journal of Agricultural Sciences 2: 46-58.

La Habi, M., Z. Kusuma, dan Widianto. 2007. Kajian Cara Pemberian dan Dosis Ela Sagu Terhadap Erosi Tanah, Limpasan Permukaan Serta Pertumbuhan dan Hasil Jagung di Ultisol. Tesis. Universitas Brawijaya.

La Habi, M., Z. Kusuma, S. Prijono, dan B. Prasetyo. 2012. Ketersediaan fosfat, serapan fosfat dan hasil tanaman jagung akibat pemberian pupuk organik granul ela sagu dengan pupuk fosfat pada inceptisol. Plumula: Berkala Ilmiah Agroteknologi 1: 144-155.

La Habi M., B. Prasetya, S. Prijono, and Z. Kusuma. 2012. The effect of sago pith waste granule compost and inorganic fertilizer on soil physical characteristics and corn (Zea mays L.) production in inceptisol. IOSR Journal of Environmental, Toxicology and Food Technology 8: 32-40.

Ouda, B.A. and A.Y. Mahadeen. 2008. Effect of fertilizers on growth, yield, yield components, quality and certain nutrient contents in broccoli (Brassica oleraceae). International Journal of Agriculture \& Biology 10: 627-632.

Purseglove, J.W. 1972. Tropical Crops Monocotyledons, Longman Group Ltd, London. Pp 38-50.

Sardi, K., and E. Timar. 2005. Response of garlic (Allium sativum L.) to varying fertilization levels and nutrients ratios. Communications in Soil Science and Plant Analysis 36: 673-679. https://doi.org/10.1081/CSS-200043326

Seran, T.H., S. Srikrishnah, and M.M.Z. Ahamed. 2011. Effect of different levels of inorganic fertilizers and compost as basal application on the growth and yield of onion (Allium cepa L.). Journal of Agricultural Sciences - Sri Lanka 5: 64-70. DOI: http://doi.org/10.4038/jas.v5i2.2783

Stevenson, F.J. and M.A. Cole. 1999. Cycles of soil. Second Edition. John Wiley \& Sons, London.

Suryaningsih, E. dan A.A. Asandhi. 1992. Pengaruh pemupukan sistem petani dan sistem berimbang terhadap intensitas serangan penyakit cendawan pada bawang merah (Allium ascalonicum L.). Buletin Penelitian Hortikultura 24: 19-26. 
Suwandi, 1998. Optimasi Input Produksi Budidaya Sayuran. Inovasi Teknologi Pertanian. Seperempat Abad Penelitian Pengembangan Pertanian. Badan Litbang Pertanian. P. 540-549.

Suwandi, dan T.K. Moekasan. 2008. Penentuan paket teknologi budidaya bawang merah di dataran rendah dan medium melalui pendekatan analisis model indeks komposit. Jurnal Hortikultura 18: 420-429. DOI: http://dx.doi.org/10.21082/jhort. v18n4.2008.p\%25p 